\title{
Los problemas políticos de Irán desde el punto de vista de las mujeres viajeras en la era Nasseri
}

\author{
Iran's Political Problems from the Viewpoint of Female Travelers in the Nasseri Era
}

\author{
Seyed Mohiedin Khalkhali ${ }^{1}$, Mohammad Kalhor ${ }^{2 a}$ \\ Yadegar-e-Imam Khomeini (RAH) Shahre Rey Branch, Islamic Azad University,Tehran, Iran ${ }^{12}$ \\ (iD) Orcid ID: https://orcid.org/0000-0001-5293-28601 \\ (iD) Orcid ID: https://orcid.org/0000-0002-3055-320X ${ }^{2}$
}

Recibido: 28 de marzo de 2020

Aceptado: 25 de octubre de 2020

\section{Resumen}

El objetivo de este estudio fue analizar los problemas políticos de Irán desde el punto de vista de las mujeres viajeras en la era Nasseri. Esta investigación se ha realizado mediante el método descriptivo y mediante el estudio de trabajos escritos e históricos. Los investigadores han extraído material examinando libros, artículos y escritos históricos. Asimismo, se recopila e soluciona los problemas de los pasajeros. Los resultados muestran que durante la Era Qajar, debido a la posición estratégica de Irán y el Golfo Pérsico, esta región fue de particular interés para las potencias internacionales superiores; por lo tanto, viajaban a Irán viajeros, estadistas, embajadores y comerciantes de muchos países europeos y no europeos. En estas delegaciones y grupos políticos extranjeros también hubo figuras femeninas, entre ellas Lady Sheil, Jane Dieulafoy, Gertrude Bell, Madame Wolfson, Isabella Bird Bishop y Carla Serena. Algunas de estas mujeres llegaron a Irán como miembros de delegaciones políticas y otras con fines turísticos o económicos. Con respecto a su estatus y posición, proporcionaron a los funcionarios de Qajar informes en los que abordaban los problemas políticos de Irán, como el fracaso del gobierno en la gestión de la salud pública y la justicia, el manejo de la inseguridad, la corrupción económica generalizada entre los estadistas y otras autoridades del gobierno de Qajar, opresiones, y similares. Según los resultados, se puede decir que la mayoría de estos problemas están relacionados con la estructura interna de Irán así como con la cultura iraní y algunas costumbres de esa época.

Palabras clave: Irán, Era Nasseri, Era Qajar, mujeres viajeras, política, historia iraní. 


\begin{abstract}
The objective of this study was to analize the Iran's Political Problems from the Viewpoint of Female Travelers in the Nasseri Era. Refering to the methodology: this research has been done by descriptive method and by studying written and historical works. Researchers have extracted material by examining historical books, articles and writings. In this study, we have tried to collect and sort out the problems of passengers. Results show that during Qajar Era, due to the strategic position of Iran and the Persian Gulf, this region was of particular interest to the superior international powers; therefore, travelers, statesmen, ambassadors, and merchants from many different European and non-European countries traveled to Iran. In these foreign delegations and political groups, there were also female figures, including Lady Sheil, Jane Dieulafoy, Gertrude Bell, Madame Wolfson, Isabella Bird Bishop and Carla Serena. Some of these women came to Iran as members of political delegations and some for tourism or economic purposes. Regarding their status and position, they provided Qajar officials with reports in which they addressed Iran's political problems, such as the government's failure in managing public health and justice, dealing with insecurity, widespread economic corruption among statesmen and other authorities of Qajar government, oppressions, and the like. According to the results, it can be said that most of these problems are related to the internal structure of Iran as well as the culture of Iranians and some customs of that time.
\end{abstract}

Keywords: Iran, Nasseri Era, Qajar Era, women travelers, politics, Iranian history.

\title{
Introduction
}

The reign of Naser al-Din Shah Qajar, which lasted for fifty years, was marked by intense colonial competitions in the East. Therefore, various individuals, including businessmen, ambassadors, tourists, political agents, physicians, botanists, archaeologists, etc. from European governments traveled to Iran to be acquainted with the culture, customs, ethical and social characteristics, and political condition of Iran as one of the most important pieces of international politics puzzle and to provide their governments with the needed information (Shamim, 2017).

One of the most important tasks of ambassadors and travelers who traveled to the eastern lands, such as Iran, was to gather information and provide a detailed report of the political, economic and social conditions for planning the future economic and political projects. Among them, there were a number of female travelers, namely Isabella Bird Bishop, who was a prominent explorer of the Nasseri Era who traveled to Iran in 1890, and her diaries and travelogue contain important information about Iran (Sykes, 2015); Carla Serena, an Italian explorer who traveled to Iran in 1877, whose reports provided useful information on the life of the women in the harem, as well as social life of people and political situation of Iran (Serena, 1983); Jane Dieulafoy, the wife of Marcel-Auguste Dieulafoy, a French architecture and archaeologist, who wrote and published 
memoirs of her travels to Iran, and they are an important source of information (Gobineau, 1988); Mary Leonora Woulfe Sheil, who accompanied her husband in most of his trips and missions and because of her prominent position as wife of the envoy, she had relationships with the women of the court, including Mahd-e Olia - Nasser al-Din Shah Qajar's mother. In 1856 she published her travel memoir which provided a lot of information about Iran (Shamim, 2017); Gertrude Margaret Lowthian Bell, known as "Iraq's Queen Mother" and "Daughter of the Desert" was one of the most influential agents of the British Intelligence during the reign of Nasser al-Din Shah Qajar and she journeyed to the East and started her activities in Iraq and the Ottoman Empire (Gobineau, 1988); finally, mention should be made of Madame Wolfson, a Russian explorer who published her memoir in 1909 in Russia, in which she provided valuable information on the chaotic situation of Iran and the causes of disorders and backwardness (Gouldm, 2016).

In light of the aforementioned background, the present study seeks to answer the question that how female travelers depicted the political problems of the Nasseri Era. Due to the spread of new political ideas in the western countries, women were influenced by such ideas and traveled to Iran. They often complained about the political, social and economic problems of Qajar government and reflected upon the political problems caused by the inefficiency and inadequacy of Qajar statesmen and kings. Therefore, because of the sharp differences between the mindset and thoughts of Iranian women and the female travelers of the Nasseri Era, investigating the political problems of Iranian society from the viewpoint of female travelers is significantly important.

\section{Methodology}

The method of this historical research is analytical. The researcher uses the method of historical research when dealing with a problem that has occurred in the past and ended in the past. In other words, the time frame is closed. The problem can be related to the recent past or the root of the valley of events that It happened a century ago (Naderi and Saif, 2018).

Historical research is a systematic and accurate study of the past, and the historian works with great skill on points about an event or a person. Historical research is the application of the scientific method to historical issues. This research is in fact a systematic search. In other documents and sources, which contain facts in the field related to the historical researcher's 
question about the past. Therefore, historical research necessarily deals with events that have taken place before the researcher's decision to study them (Delavar, 2017).

In this study, we have tried to collect and sort out the problems of passengers. during Qajar Era, due to the strategic position of Iran and the Persian Gulf, this region was of particular interest to the superior international powers; therefore, travelers, statesmen, ambassadors, and merchants from many different European and non-European countries traveled to Iran. In these foreign delegations and political groups, there were also female figures, including Lady Sheil, Jane Dieulafoy, Gertrude Bell, Madame Wolfson, Isabella Bird Bishop and Carla Serena. Some of these women came to Iran as members of political delegations and some for tourism or economic purposes.

\section{Historical-social issues in the experience of women travelers of the Nasseri era}

\section{Corruption among the Kings and Officials of Qajar Government}

Corruption refers to obtaining personal gains, promotion or fame from public office, or for the benefit of a group or class, in a way that violates the law or standards of high moral conduct, this can be an unethical or illegal behavior in financial affairs. In this context, corruption refers to the financial and economic misconduct, plunder, extortion and abuse of power. Qajar kings and officials received bribes and ignored any inappropriate act or unlawfulness and even refrained from punishing criminals. The causes of widespread economic corruption among all classes of Iranian people during Qajar era were the irregularity of earnings, insecurity and lack of central control over affairs, employees, governors, and rulers. According to the travelers, non-payment of salaries of the lower-class servants and employees was a reason that they were interested in receiving bribes, otherwise, they were not able to make a living. "If government employees live only on their low salary, which is rarely paid, they will die from starvation. So, they constantly seek to find a way to make a living. They forced businessmen and taxpayers to pay bribes" (Gobineau, 1988, p. 382).

The other immoral act among agents and officials of Qajar government in the era of Nasser al-Din Shah was the collusion of government agents with thieves and bandits in plundering people's properties. During her trip to Tabriz, Madame Dieulafoy wrote a story about the collusion of security chiefs with the thieves which clearly illustrates the depth of this corruption. Generally, the governors and princes ruling the tribes and provinces believed that punishing thieves and robbers was an unreasonable act; they found it wiser to imprison and then release them by receiving the offerings and bribes (Sykes, 2015; 598). Serena has also written about plundering people during king's travels; although the king usually paid for his trips, officials forced the residents of the villages and rural regions to provide the king with free equipment and necessities. According to her, the king was aware of this, but did not protest and was stratified with the condition. She writes: 
Another important aspect of corruption in the Nasseri Era was the bizarre tradition of selling government positions. In Qajar era, government positions and posts were auctioned off, and anyone who offered more money or bribes to the officials and the king would won the desired position (Shamim, 2017). This led to widespread chaos and disorder in the country, because the governor, after being appointed to the office, extorted the money he had spent as bribes from the helpless people and even tried to make more money as a profit and resorted to any means in doing so. Bishop writes: Madame Wolfson also mentions in her travelogue that "... none of the positions and promotions is given to the officials without receiving bribes" (Wolfson, 1930; 113).

Another point that female travelers mentioned in their memoirs is the corruption in the administrative and governmental system of Qajar dynasty, indicating king's and government agents' inefficiency. These women noted that the king had no interest in governmental affairs and was inclined to having fun with trivial pleasures. He never supervised his subordinates and provincial rulers. According to the sources, the king almost never investigated the affairs conducted by the officials and governors in order to improve the state's condition and to punish the transgressors.

Madame Serena reported that, when the king was visiting the city before traveling to Europe, some soldiers submitted him a letter in which they had written about their payback. The king ordered them to go away without reading the letter, but a struggle happened between the angry soldiers and the servants. During the struggle, a little rock struck the king's carriage. One of the companions who was wounded in the incident, with some drops of blood on his face, approached to the carriage to ingratiate himself with the king by the news and shouted: "Your Majesty, save yourself! They are making an attempt on the king's life!" The king was frightened. By his order, they arrested the soldiers, killed ten and punished the others. After a while, Nasser al-Din Shah read the letter and found the truth. He ordered the officials involved in the incident to pay the bloodmoney of the killed ones (Serena, 1983: 287). Therefore, Qajar's incompetent and opportunist agents only pursued their own interests and easily violated the king's order if it was against their own wishes: "... although he (Nasser al-Din Shah) is a tyrant, his orders are not executed unless they are in favor of ministers and officials" (Serena, 1983: 287).

\section{Oppression of the public by the officials}

The oppressive and cruel behavior of officials and staff, especially tribal and provincial governors, has been repeatedly cited by the explorers. Here again, the king himself was the role model of tyranny and oppression. For example, Carla Serena has written about the evacuation of streets and paths where the king's wives intended to cross. According to her, if a man looked at his wives while they were crossing the streets, he would be punished hard or even sentenced to death:

When the caravan (king's wives) is going to arrive, the servants accompanying them shout loudly: "Go away, go blind." These warnings make people escape and evacuate the path. In dead-end alleys, every man who hears this sentence should return to the main path, turn 
his back to the women and stand still. Looking at even one of the king's wives is considered an insult and such an imprudence may cost that person's life. Anyway, the least horrible punishment is foot whipping. The lucky ones are those who are not tortured with "hair pulling" in which they pull out the hair of the individual's beard (Serena, 1983: 287).

Cruelty in taxation is another problem that is frequently found in travelogues. According to Wolfson, taxation in that era was accompanied by the savage exercise of power by the rulers and governors. When taxing, they never took problems like pests and plagues into consideration, forcing people to pay for more than they had earned:

According to the people who are aware of the general condition of the country, some extra money equivalent to two-thirds of the taxpayers' earnings was taken. The patience and tolerance of Iranian people is really shocking. The strangest of all is that none of the problems like famine, droughts and plagues are considered in taxation. (Wolfson, 1930: 109).

Bishop has also written about collecting more taxes than is absolutely necessary-i.e. the amount determined by the tax agencies. The situation was so chaotic and oppressive. In fact, all classes in this system put pressure on their subordinates and tried to allocate a percentage of taxes to themselves. Thus, far more than needed had to be paid by people. Rulers and treasurers robbed most of it and only a little amount remained for the king's court:

They [Khans of Boroujerd] say that the tax determined by the king is not that much high. But the officials take more than is necessary and this makes people poorer year by year. They also say that when they refuse to pay the tax imposed by Amin al-Sultan (the Chancellor), the ruler and soldiers forcibly confiscate their herd and sometimes they take about three to five times as much as the debt from the people. . I think all officials, from the superiors to the subordinates, are under the king's pressure, so they try to collect as much as they can (Bishop, 1996: 231).

In addition to what was mentioned in Bishop's travelogue, she has pointed to other issues regarding the pressure imposed on people and oppression by the rulers and officials. (Bishop, 1996: 231). For that, people were under pressure to pay taxes and it caused riots and devastation in the towns and cities: "I was deeply sorry to see that the residents of Boroujerd have rebelled against a high-ranking official and ruined his territory because of his cruelty in collecting annual taxes" (Bishop, 1996: 231).

\section{Insecurity and banditry}

When it comes to security, one of the important components that must be taken into consideration is the violation of social and religious laws. In the writings of the travelers, examples of non-compliance with religious laws and social norms can be seen. This non-compliance resulted from the government's failure in supervising the society and officials. The king, like others, easily violated or changed the laws for his own benefits. Such conditions led to the formation of sit-in 
protests. In fact, since there was no authority to be held accountable, people resorted to sit-in. Lady Sheil writes:

Although there are apparently a number of laws in Iran, almost none of them are executed. Because factors like relationships and hostilities, instigations, corruption and exercising power constantly overturn laws and in recognizing right and wrong, they consider personal interests rather than the law. In such a society, sit-in protest is inevitable (Sheil, 1983: 116).

On the other hand, the lack of supervision over provinces and villages led to the spread of chaos, insecurity, corruption, banditry and riots all over the country. Routes were unsafe due to ethnic conflicts and banditry, so caravans and mailmen could not safely travel and would always be accompanied by a group of guards to survive the robbers. Even in such circumstances, no measure was taken by the rulers, governors or even the king, and as noted by many of the travelers, the official also conspired with the thieves. This situation ruined the country and made people abandon caravan routes and take refuge in remote places. In Dieulafoy's travelogue, she has written about the destruction of Azerbaijani through robbery and plunder:

This province (Azerbaijan) has turned into a lifeless desert. We see no tree to shelter ourselves in its shadow. We hardly encounter a village in our way. Since our arrival, we have seen farmers gathered in an area living in mud houses because they are afraid of the thieves (Dieulafoy, 1982: 36).

As mentioned earlier, caravan routes were always exposed to the robber's attack. One of these regions was a western area which was the residence of Bakhtiari Nomads. According to the travelers, there was always tribal conflict between them. The constant conflicts between the two Bakhtiari tribes of Haft Leng and Chahar Leng have been recorded in the history of this country and even the travelers have mentioned this. According to Bishop, the said conflicts happened because of different reasons; power, land, pasture and trivial issues. They often lasted for years and many people were killed during them (Bishop, 1996: 48).

In addition to chaos and murder, these circumstances often led to war and insecurity. In such situations, it was impossible to travel in these regions and it might end at the expense of people's life. As stated, these conditions led to the insecurity of important trade roads. In her travelogue, Bishop has written about the insecurity of the road connecting Khouzestan to central regions of Tehran:

... A part of Shoushtar-Boroujerd road which is the most important trade road connecting the North, South and West regions of Iran, cannot be used to carry non-commercial goods because a part of this road crosses Filli's Territory. It is always dangerous and unsafe due the tribal conflicts. Caravans and travelers are often robbed by the thieves (Bishop, 1996: 48). 
In addition, Bishop has written about the bandit attacks to mailmen: "A mailman carrying a letter from Boroujerd to Douglas was robbed by the thieves in the middle of the road." In her trips to Bakhtiari regions, Bishop has repeatedly written about the insecurity of the road and the bandits and thieves robbing caravans and travelers (Bishop, 1996: 48).

\section{Health issues as reported by main female travelers during the Nasseri era}

Failure to address public health in the country, failure to deal with epidemics, failure to establish quarantine facilities during outbreaks, Shortcomings in educating people, failure of the government in preventing contamination of drinking water and disposing waste in streets that released infection and eventually led to the spread of epidemics and death of many people, are among the other items that the travelers of the Nasseri Era have mentioned.

According to them, in all seasons of the year, especially summer, various contagious diseases, especially "cholera" spread everywhere, leading to the death of many; however, the government took no measure to deal with it. The king and the royal family usually took refuge in the countryside to save their lives and get rid of the hard conditions. The frequent outbreaks of the epidemics and the lack of government supervision and shortcomings in taking necessary measures confounded many of the travelers like Dieulafoy. She writes: "Dear Lord! What a country it is! I have seen sick people everywhere since I have arrived” (Dieulafoy, 1982: 409).

As mentioned, the government's only precautionary measure was to leave cities and reside in the countryside; the Europeans residing in Tehran and other cities were recommended to spend the summer (when the disease worsened) in cool regions. Ordinary people also left the cities and went to a safer place. According to Gertrude Bell, when cholera was epidemic throughout Mashhad, half of the people died and others fled the city, and the city was completely evacuated (Bell, 1984: 48).

Travelers have mentioned various causes for the expansion of the epidemics in Iran. Dirty cities and lack of government supervision on the cleanliness of passages and alleys were among the reasons. During this period, people disposed their domestic waste and wastewater into the streets which polluted the environment. Despite the increasing environmental pollution, the government took no action to prevent it. Madame Dieulafoy wrote about this problem in Bushehr and other cities of Iran:

The open-pit toilets are located in the alleys. This unpleasant condition is seen in all cities, but it is far worse in this town. The upper floors of residential buildings lack pipes, so they throw excrement and other rubbish out in the alley. The pedestrians have to walk carefully and they would be very lucky if the rubbish is not poured on their heads. Although Islam emphasizes on cleanliness, I cannot understand why Muslims do not observe hygiene (Dieulafoy, 1990: 540). 
Neglecting water resources and polluting the rivers and streams which provided drinking water for residential areas was another cause of the frequent outbreaks of different diseases. Illiteracy led to the unawareness of people about the cause of disease and doing such actions. But the government, being at the top of the society, including literate elites, failed at making an attempt to prevent them. Gertrude Bell's travelogue refers to the unawareness of people and lack of attention to keep water resources healthy. According to her, the corpses of those who had died from cholera were washed in the stream which supplied drinking water for the villages and towns. In addition, Gertrude Bell stated the lack of precautionary facilities, such as the establishment of quarantine, construction of hospitals, etc. by the government at the time of the outbreaks of epidemics:

Cholera was approaching in the early summer ... Telegraphs reported that cholera was severe in Samarkand. An inappropriate quarantine was established between Tehran and the infected area... Finally, cholera seized the Caspian Sea in a moment. Although they got aware, they did not provide any equipment to deal with it, did not construct any hospital, and did not establish any aiding system. The carts full of infected fruit were still allowed to enter the city and the air was still poisoned by the trash being left on the streets (Dieulafoy, 1990: 540).

Isabella Bird Bishop was a prominent explorer of the Nasseri Era who traveled to Iran in 1890/1269 AH. She suffered from spinal cord disorders and decided to travel to improve her condition as her physician had recommended. Travels reduced her pain and encouraged her to go on long trips around the world (America, Australia, Malaya, Japan, India, and Iran). She traveled to Iran at the suggestion of Major Herbert Sawyer, a member of the Indian Army. Bishop traveled for ten months to various cities of Iran, namely Tehran, Isfahan, Qom and Kashan. Bishop's diaries and travelogue contain important information about Iran (Kasra, 2017).

Carla Serena was an Italian explorer who traveled to Iran in 1877/1292 AH. That year was the $30^{\text {th }}$ anniversary of Nasser al-Din Shah Qajar's reign. After a long journey in the Caucasus and northwestern regions, she traveled to Iran through The Caspian Sea to cure a sickness caused by the humid weather of Baku. During her trip, she visited Nasser al-Din Shah's harem and provided useful information on the life of the women in the harem, as well as social life of people and political situation of Iran (Kasra, 2017).

Jane Dieulafoy was the wife of Marcel-Auguste Dieulafoy, a French architecture and archaeologist. In the Nasseri Era, French Government sent Marcel-Auguste Dieulafoy to Iran for three times to explore ancient Iranian sites. His wife accompanied him on his trips. Madame Dieulafoy wrote and published memoirs of her travels in two separate books. Her first book " $\mathrm{La}$ Perse, la Chaldée et la Susiane” is an important source of information on Qajar history that contains various information on social, political and economic situation of Iran. Dieulafoy's travels with her husband continued from 1881 to 1886 (Sheibani, 2016).

Mary Leonora Woulfe Sheil was the wife of the British envoy. He and his wife stayed in Iran from 1849 to 1853 . She accompanied her husband in most of his trips and missions and 
because of her prominent position as wife of the envoy, she had relationships with the women of the court, including Mahd-e Olia - Nasser al-Din Shah Qajar's mother. In 1856, she published her travel memoir which provided a lot of information about Iran.

Gertrude Margaret Lowthian Bell, known as "Iraq's Queen Mother" and "Daughter of the Desert" was one of the most influential agents of the British Intelligence during the reign of Nasser al-Din Shah. Later, Bell journeyed to the East and started her activities in Iraq and the Ottoman Empire. Gertrude Bell was initially a simple spy, but along with Thomas Edward Lawrence, she gradually gained experience and through encouraging the Arab tribes against the Ottomans, had a great contribution in the creation of new states like Syria, Iraq, Jordan and Kuwait. In 1893, as a consultant to the British ambassador of Iran, Bell traveled to Iran as a mission. Her memoir of a six-month trip to Iran contains important information on Iranian politics and society (Sheibani, 2016).

Madame Wolfson was a Russian explorer who traveled to Iran in 1880. She traveled to the northern regions of Iran, the Caspian Sea and Tehran. She published her travel memoir in 1909 in Russia, in which she provided valuable information on the chaotic situation of Iran and the causes of disorders and backwardness (Sheibani, 2016).

\section{Reflective analysis on the role of female travelers in the Nasseri Era}

According to the prevailing view in the history of Iran and the prevalence of court and political histories, women have been neglected and they themselves did not have the opportunity to appear in the guise of a historian or writer, but after the developments that followed the acquaintance with the Western world, Iranians came to foreign countries, translated European works, expanded associations and schools, women turned to cultural, social and sometimes political activities, and some of them wrote memoirs and travelogues and left their own works (Zahid and Khajehnuri, 2018).

We were seriously acquainted with the manifestations of the new civilization in the Nasserite period, but society faced serious challenges in the field of social and cultural relations. Women still did not have the right to read and write, and even during the constitutional period, when there were many freedoms compared to the Nasserite era, women continued to go to school strongly. In addition to a heavy social outlook, families were unfamiliar with these issues and avoided them (Sheibani, 2016).

Here we are dealing with travelogues that have very useful research margins that may not be easily accessible elsewhere. Provides a wealth of geographic and historical information about people and homes along the way that demonstrates their culture and knowledge. To understand the importance of these travelogues and their authors, we must look at the context and social context of the time of these travelogues (Kasra, 2017).

Now let's look at this from another angle. Traveling, especially long journeys, has faced many dangers. Transportation was scarce and communication was unsafe. Banditry and theft 
existed in most areas and roads of Iran. Government officials inflicted numerous abuses on ordinary people and travelers. These cases were related to inside Iran and they faced more problems outside of Iran. The language of communication was different from others (Najmi, 2012).

The present study investigated the political problems of Qajar era from the perspectives of the travelogues written by Madame Dieulafoy, Gertrude Bell, Bishop, Carla Serena, Madame Wolfson and Lady Sheil. In Qajar era, due to the international political conditions, European officials and travelers frequently traveled to Iran. Iran as a country being located in the neighborhood of India and the Persian Gulf was always highly regarded by colonial countries such as Britain, Russia and France. India, the golden colony of Britain, was always considered as a precious region by Russia and France and many attempts were made by the above-mentioned governments to seize India through Iran and the Persian Gulf. Therefore, the British attempted to identify the political-social conducts of Iranians as well as Qajar statesmen and kings to both persuade and motivate the officials and to prevent the influence of the enemy. In addition, other European governments took similar actions to find the way to penetrate the country by dispatching political agents or inviting tourists to report the details of Iran's political and social conditions. In this regard, political agents and tourists, including women, collected information on Iran's political shortcomings and problems, and wrote about the corruption of Qajar kings and government officials as well as the high interest of the members of the Qajar government in receiving bribes and the effect of bribery in progressing all affairs. On the other hand, they wrote about the oppression, extortion and taking people's earnings forcibly as taxes, insecurity, tribal conflicts and riots, and the government's failure in paying attention to public health which resulted in yearly outbreaks of epidemics and the death of many people.

According to the results what they have reflected upon in their writings, is important and useful information which greatly helped colonial governments in planning and achieving their desired goals in Iran. Since then, due to the bribe-taking spirit of the Qajar officials and dissatisfaction of people, the colonial governments achieved their purposes and goals by forcing some dissatisfied people to rebel or to pay bribes to officials.

\section{Conclusion}

According to the results, it can say that during Qajar Era, due to the strategic position of Iran and the Persian Gulf, this region was of particular interest to the superior international powers; therefore, travelers, statesmen, ambassadors, and merchants from many different European and non-European countries traveled to Iran. In these foreign delegations and political groups, there were also female figures, including Lady Sheil, Jane Dieulafoy, Gertrude Bell, Madame Wolfson, Isabella Bird Bishop and Carla Serena. Some of these women came to Iran as members of political delegations and some for tourism or economic purposes. Regarding their status and position, they provided Qajar officials with reports in which they addressed Iran's political problems, such as the government's failure in managing public health and justice, dealing with insecurity, widespread 
economic corruption among statesmen and other authorities of Qajar government, oppressions, and the like.

Examining the travelogues of the Qajar period, we come to the conclusion that the narrations that are passed on in the travelogues to the next generations and mainly historians, enable them to address less social, cultural and sometimes economic issues in their research. It is important for outside historians to look at issues that are common to contemporary historians. It can be said that in travelogues we will find a lot of important information that is the result of the difference between the views of travel writers and historians. Now, if the author of the travelogue is a woman, this importance will be doubled due to the kind of look, accuracy and delicacy in recording the details of the affairs.

\section{References}

Bell, G. (1984). Persian Pictures. Tehran, Iran: Kharazmi publisher.

Bishop, I. B. (1996). Journeys in Persia and Kurdistan. Tehran, Iran: Sahand publisher.

Delavar, A. (2017). Theoretical and practical foundations of research in humanities and social sciences. Sixth edition. Tehran, Iran: Roshd Publications, new edition.

Dieulafoy, J. (1982). La Perse, la Chaldée et la Susiane. Tehran, Irán: Khayam publisher.

Dieulafoy, J. (1990). La Perse, la Chaldée et la Susiane. Tehran, Irán: University of Tehran press. Gobineau, J. A. (1988). Trois ans en Asie. Tehran, Irán: Nashrenow publisher.

Gouldm, J. (2016). A Dictionary of the Social Sciences. Tehran, Irán: Maziar publisher.

Kasra, N. (2017). Women in the Qajar in Politics. Tehran, Irán: Negah Publisher, new edition.

Naderi, A., Saif Naraqi, M. (2018). Research methods and how to evaluate it in the humanities (with up to one on educational sciences). nineteen edition. Tehran, Irán: Arasbaran Publishing.

Najmi, N. (2012). Tehran Nasser era. Tehran, Irán: Attar Publisher.

Serena, C. (1983). Hommes et Choses en Perse. Tehran, Irán: Nashrenow publisher.

Serena, C. (1984). Hommes et Choses en Perse. Tehran, Irán: Nashrenow publisher.

Shamim, A. (2017). Iran During the Qajar Reign; the $13^{\text {th }}$ Century and the First Half of $14^{\text {th }}$ Century. Tehran, Iran: Zaryab publisher.

Sheibani, J. (2016). European trip to Iran. translated by Seyyed Zia-ud-Din Dehshiri, Tehran, Iran: Scientific and cultural Publication.

Sheil, A. L. (1983). Glimpses of life and manners in Persia. Tehran, Iran: Ketabsara publisher. 
Sykes, P. (2015). Ten Thousand Miles in Persia: Or, Eight Years in Irán. Tehran, Iran: Donyaye ketab publisher.

Wolfson, A. S. (1930). Iranians in the past and Present. Tehran, Iran: Bina publisher.

Zahid, S., and Khajehnuri, M. (2018) Women's Movement in Iran. Shiraz, Iran: King Suleiman publisher. 